\title{
Penggunaan Obat Antihipertensi pada Pasien Hipertensi Esensial di Poliklinik Ginjal Hipertensi RSUP DR. M. Djamil Tahun 2011
}

Heri Fitrianto ${ }^{1}$, Syaiful Azmi ${ }^{2}$, Husnil Kadri ${ }^{3}$

\begin{abstract}
Abstrak
Penyakit hipertensi tidak dapat disembuhkan dan berkaitan erat dengan penurunan usia harapan hidup. Penderita hipertensi juga sering kali disertai oleh penyakit penyerta. Umumnya, golongan obat antihipertensi yang dikenal yaitu, diuretik, ACE Inhibitor, Angiotensin Reseptor Bloker, Canal Calcium Blocker, and Beta Blocker. Terapi yang diberikan pada penderita hipertensi tanpa penyakit penyerta dan dengan penyakit penyerta tentunya berbeda. Tujuan penelitian ini adalah mengetahui penggunaan obat antihipertensi antara pasien hipertensi esensial dengan penyakit penyerta dan yang tidak disertai dengan penyakit penyerta di poliklinik RSUD Dr. M. Djamil, Padang. Metode penelitian yang digunakan adalah deskriptif dengan mengambil data dari rekam medik. Data dari 380 pasien yang dikumpulkan selama periode Januari 2011 sampai dengan Desember 2011. Jumlah subjek ditentukan dengan teknik total sampling. Dari data penelitian didapatkan bahwa 277 pasien hipertensi tanpa penyakit penyerta dan sebanyak 103 pasien hipertensi dengan penyakit penyerta. Komposisi dari 103 pasien hipertensi dengan penyakit penyerta yaitu 63 pasien dengan diabetes melitus, 13 pasien dengan PJK, 13 pasien dengan stroke, 7 pasien dengan gagal jantung, 4 pasien dengan pasca infark miokard, 3 pasien dengan gagal ginjal kronik. Berdasarkan data penelitian didapatkan penggunaan obat antihipertensi yang sering digunakan yaitu Hidroklortiazid (35,5\%), Captopril (26,2\%), Valsartan $(20,6 \%)$, Amlodipin (15,2\%), dan obat antihipertensi lain (2,5\%). Berdasarkan hasil penelitian disimpulkan bahwa hipertensi dengan penyakit penyerta terbanyak adalah diabetes melitus dan penggunaan obat terbanyak berasal dari golongan diuretik yaitu penggunaan Hidroklortiazid.
\end{abstract}

Kata kunci: obat antihipertensi, hipertensi, diuretik

\begin{abstract}
Hypertension can not be cured and is closely related to a decrease in life expectancy. Patients with hypertension are also often accompanied by complience indication. Generally, antihypertensive drug classes are known, namely, diuretic, ACE Inhibitor, Angiotensin Reseptor Bloker, Canal Calcium Blocker, and Beta Blocker. Therapy which given to patients with or without complience indications is certainly different. The objective of this study was to determine the usage of anti-hypertension medicine in essential hypertension patients with or without complience indications in policlinic of General Hospital Dr. M. Djamil Padang. This was a descriptive study which the data were taken from medical record. The 380 patient's data in period January 2011 - December 2011. The number of subjects was determined by the total sampling. The data showed 277 hypertension patients without complience indications and 103 hypertension patients with complience indications. Compositions of 103 hypertension patients with complience indications are 63 patients with diabetes mellitus, 13 patients with PJK, 13 patients with stroke, 7 patients with heart failure, 4 patients with post-infarct myocardium, and 3 patients with chronic kidney failure. Concerning the usage of anti-hypertension medicines which were frequently i.e. Hidroclortiazid (35,5\%), Captopril (26,2\%), Valsartan (20,6\%), Amilodipin (15,2\%), and other anti-hypertension drugs (2,5\%). Based on the results of this study are concluded that complience indications suffered by most hypertension patients is diabetes mellitus and the usage of medicine by most patients is from diuretic which is Hidroclortiazid.
\end{abstract}

Keywords: antihypertension drugs, hypertension, diuretics

Affiliasi penulis: ${ }^{1}$ Fakultas Kedokteran Unand, ${ }^{2}$ Bagian IImu Penyakit Dalam Fakultas Kedokteran Unand, ${ }^{3}$ Bagian Biokimia Fakultas Kedokteran Unand,

Korespondensi: Heri Fitrianto. Email : husnilbiokimia@yahoo.com

\section{PENDAHULUAN}

Peningkatan tekanan darah berkaitan erat dengan penurunan usia harapan hidup seseorang dan peningkatan risiko penyakit jantung koroner, stroke, serta penyakit organ target lainnya. Meningkatnya prevalensi hipertensi setiap tahun menjadi masalah utama di negara berkembang dan negara maju. Berdasarkan data Global Burden of Disease (GBD) tahun 2000, 50\% dari penyakit kardiovaskuler disebabkan oleh hipertensi. ${ }^{1}$ Data dari The National Health and Nutrition Examination Survey (NHANES) menunjukkan bahwa dari tahun 1999 sampai dengan 2000 , insiden hipertensi pada orang dewasa adalah sekitar 29-31\%, yang berarti terdapat 58-65 juta penderita hipertensi di Amerika, dan terjadi peningkatan 15 juta dari data NHANES tahun 1988$1991 .^{2}$

Hipertensi esensial merupakan hipertensi yang tidak diketahui penyebabnya. Data epidemiologi menunjukkan bahwa semakin meningkat populasi usia lanjut maka jumlah pasien dengan hipertensi kemungkinan besar juga akan bertambah. Hipertensi 
sering timbul pada lebih dari separuh orang yang berusia $>65$ tahun. ${ }^{2}$

Tujuan terapi hipertensi adalah menurunkan morbiditas dan mortalitas dengan cara yang paling nyaman. Berdasarkan alogaritma yang disusun JNC VII, terapi paling dini adalah mengubah gaya hidup. Jika hasil yang dinginkan tak tercapai maka diperlukan terapi dengan obat. Secara umum, golongan obat antihipertensi yang dikenal yaitu, diuretik, ACE inhibitor, Angiotensin Resptor Bloker, Canal Calsium Bloker, dan Beta Bloker. ${ }^{3}$

Penderita hipertensi sering kali diserta dengan penyakit penyerta. Penyakit penyerta yang dimaksud adalah diabetes melitus, penyakit ginjal kronis, pasca infark miokard, penderita gagal jantung, stroke, dan resiko tinggi penyakit jantung koroner. Terapi yang diberikan pada penderita hipertensi tanpa penyakit penyerta dan dengan penyakit penyerta tentunya berbeda. ${ }^{2}$

Penelitian ini dilakukan di RSUP dr. M. Djamil Padang karena rumah sakit ini merupakan rumah sakit rujukan tertinggi di provinsi Sumatera Barat. Dengan dilatar belakangi oleh uraian diatas, maka penelitian ini bertujuan untuk mengetahui penggunaan obat antihipertensi esensial di poliklinik ginjal hipertensi RSUP dr. M. Djamil, Padang.

\section{METODE}

Data diambil di bagian rekam medik RSUP dr. M. Djamil dari Mei 2012 sampai dengan Juli 2013. Penelitian deskriptif ini menggunakan status rekam medis pasien yang didiagnosis hipertensi di bagian Penyakit Dalam tahun 2011. Populasi adalah seluruh data rekam medik pasien hipertensi RSUP DR. M. Djamil Padang pada tahun 2011 sebanyak 505 kasus. Penentuan jumlah sampel menggunakan teknik total sampling. Kriteria inklusi yaitu seluruh catatan rekam medis pasien yang mendapat diagnosis akhir sebagai hipertensi esensial dengan dan tanpa penyakit penyerta. Kriteria eksklusi adalah seluruh catatan rekam medis pasien yang didiagnosis hipertensi esensial tapi tidak mendapat terapi obat antihipertensi atau data rekam medis yang tidak dapat terbaca dengan jelas. Kemudian data tersebut ditabulasikan dan ditampilkan dalam bentuk tabel distribusi frekuensi dan gambar.

\section{HASIL DAN PEMBAHASAN}

Berdasarkan kriteria sampel yang diperlukan didapatkan 380 data pasien yang memenuhi kriteria atau sekitar $75 \%$ dari data yang ada.

Tabel 1. Distribusi pasien hipertensi berdasarkan pemenuhan kriteria sampel

\begin{tabular}{lll}
\hline Data & Jumlah & $\begin{array}{l}\% \\
\text { PasienHipertensi } \\
\text { papertensi. }\end{array}$ \\
\hline $\begin{array}{l}\text { Data pasien yang } \\
\text { memenuhi kriteria }\end{array}$ & 380 & $75 \%$ \\
$\begin{array}{l}\text { Data pasien yang } \\
\text { tidak memenuhi }\end{array}$ & 125 & $25 \%$ \\
kriteria & & \\
\hline Total & 505 & $100 \%$ \\
\hline
\end{tabular}

\section{A. Usia}

Tabel 2. Distribusi pasien hipertensi berdasarkan usia

\begin{tabular}{lll}
\hline Usia & $\begin{array}{l}\text { Frek } \\
\text { uens } \\
\text { i }\end{array}$ & $\begin{array}{l}\text { Persentase }(\%) \\
\text { dari keseluruhan } \\
\text { pasien hipertensi } \\
\text { esensial }\end{array}$ \\
\hline $\begin{array}{ll}\text { <30 tahun } \\
\text { 30-39 tahun }\end{array}$ & 7 & 1,8 \\
$40-49$ tahun & 72 & 4,3 \\
$50-59$ tahun & & \\
& 124 & 32,6 \\
260 tahun & 161 & 42,4 \\
\hline Total & 380 & 100 \\
\hline
\end{tabular}

Mengacu pada tabel di atas didapatkan bahwa penderita pasien hipertensi pada usia < 30 tahun sebanyak $1,8 \%$ (7 orang). Persentase ini terus meningkat seiring bertambahnya usia.

\section{B. Jenis Kelamin}

Tabel 3. Distribusi pasien hipertensi esensial berdasarkan jenis kelamin

\begin{tabular}{lll}
\hline Jenis Kelamin & Jumlah & $\begin{array}{l}\% \\
\text { hipertensi } \\
\text { berdasarkan jenis } \\
\text { kelamin. }\end{array}$ \\
\hline Laki - laki & 188 & 49,5 \\
Perempuan & 192 & 50,5 \\
\hline Total & 380 & 100 \\
\hline
\end{tabular}

Berdasarkan tabel distribusi di atas, di dapatkan bahwa prevalensi pasien hipertensi pada perempuan sedikit lebih tinggi $1 \%$ dari total keseluruhan pasien dibandingkan dengan prevalensi pada laki-laki.

\section{Terapi}

Tabel 4. Distribusi jenis terapi yang didapat pada saat pelayanan kesehatan

\begin{tabular}{lllr}
\hline Jenis terapi & Jumlah & $\begin{array}{l}\% \text { jenis terapi } \\
\text { yang didapat } \\
\text { pada } \\
\text { pelayanan } \\
\text { kesehatan. }\end{array}$ \\
\hline Monoterapi & 128 & 33,7 \\
Politerapi & 252 & 66,3 \\
\hline Total & 380 & 100 \\
\hline
\end{tabular}

Berdasarkan tabel distribusi di atas, di dapatkan bahwa jenis terapi yang didapat pada saat pelayanan kesehatan pada monoterapi lebih tinggi $4,6 \%$ dari politerapi pada saat mendapatkan pelayanan kesehatan.

\section{Derajat Hipertensi}

Tabel 5. Disrtibusi derajat hipertensi

\begin{tabular}{llll}
\hline Derajat Hipertensi & Jumlah & $\begin{array}{l}\% \text { jumlah pasien } \\
\text { hipertensi } \\
\text { berdasarkan derajat } \\
\text { hipertensi yang } \\
\text { diderita. }\end{array}$ \\
\hline Hipertensi derajat 1 & 143 & 37,6 \\
Hipertensi derajat 2 & 237 & 62,4 & \\
\hline Total & 380 & 100 & \\
\hline
\end{tabular}


Berdasarkan tabel distribusi di atas, didapatkan bahwa jumlah pasien hipertensi berdasarkan derajat hipertensi yang diderita sebanyak 237 pasien untuk hipertensi derajat 2 atau sekitar $62,4 \%$ dari 380 pasien.

\section{E. Hipertensi dan penyakit penyerta}

Tabel 6. Klasifikasi hipertensi

\begin{tabular}{lll}
\hline Jenis hipertensi & Jumlah & $\begin{array}{l}\% \text { Data } \\
\text { hipertensi }\end{array}$ \\
\hline $\begin{array}{l}\text { Hipertensi tanpa } \\
\text { Penyakit Penyerta }\end{array}$ & 277 & 72,9 \\
$\begin{array}{l}\text { Hipertensi dengan } \\
\text { Penyakit Penyerta }\end{array}$ & 103 & 27,1 \\
\hline Total & 380 & 100 \\
\hline
\end{tabular}

Berdasarkan tabel distribusi di atas, di dapatkan bahwa jumlah pasien hipertensi berdasarkan tanpa adanya penyakit penyerta sebanyak 277 pasien (72,9\%) dan untuk pasien hipertensi dengan penyakit penyerta sebanyak 103 pasien $(27,1 \%)$.

Tabel 7. Penyakit penyerta yang menyertai hipertensi

\begin{tabular}{lll}
\hline Penyakit Penyerta & Jumlah & $\%$ \\
\hline $\begin{array}{l}\text { Diabetes Melitus } \\
\text { Penyakit Jantung }\end{array}$ & 63 & 61,2 \\
Koroner & 13 & 12,6 \\
Stroke & 13 & 12,6 \\
Gagal Jantung & 7 & 6,8 \\
Infark Miokard & 4 & 3,9 \\
Gagal Ginjal Kronik & 3 & 2,9 \\
\hline Total & 103 & 100 \\
\hline
\end{tabular}

Berdasarkan tabel distribusi di atas didapatkan jumlah penyakit penyerta paling banyak yaitu diabetes melitus 63 pasien $(61,2 \%)$, selanjutnya penyakit jantung koroner 13 pasien (12,6\%), stroke 13 pasien $(12,6 \%)$, gagal jantung 7 pasien $(6,8 \%)$, pasca infark miokard 4 pasien $(3,9 \%)$, dan paling rendah dengan disertai oleh penyakit gagal ginjal kronik 3 pasien $(2,9 \%)$.

\section{F. Obat Yang Digunakan}

Tabel 8. Obat untuk terapi hipertensi esensial

\begin{tabular}{lll}
\hline Nama Obat & Jumlah & $\%$ \\
\hline Hidroclortiazid (HCT) & 222 & 35,5 \\
Amlodipin (Aml) & 95 & 15,2 \\
Captopril (Cap) & 164 & 26,2 \\
Valsartan (Val) & 129 & 20,6 \\
Furosemid (Fur) & 9 & 1,4 \\
Atenolol (Ate) & 7 & 1,1 \\
\hline Total & 626 & 100 \\
\hline
\end{tabular}

Mengacu pada tabel diatas didapatkan bahwa penderita pasien hipertensi paling banyak mendapatkan Hidroclortiazid sebagai terapi hipertensi (35,5\%), Captopril (26,2\%), Valsartan (20,6\%), Amlodipin (15,2\%), Furosemid (1,4\%), dan Atenolol $(1,11 \%)$

Berdasarkan tabel 3. didapatkan bahwa penderita hipertensi berdasarkan jenis kelamin adalah laki-laki sebanyak $49.5 \%$ dan pada perempuan sebanyak 50,5\%. Prevalensi tentang terjadinya hipertensi berdasarkan jenis kelamin masih belum menimbulkan titik jelas, hal ini disebabkan faktor hipertensi dari setiap individu berbeda dan pola hidup pada setiap darah juga berbeda. Literatur lain mengatakan prevalensi terjadinya hipertensi pada pasien laki-laki lebih tinggi dibandingkan dengan wanita. Adapun terjadinya prevalensi yang lebih tinggi pada pasien perempuan bisa dikaitkan dengan proses menopouse. ${ }^{4} \mathrm{Hal}$ ini diduga terjadinya hipertensi pada wanita erat hubungannya dengan hormon estrogen pada wanita.

Berdasarkan tabel 5. didapatkan jumlah pasien hipertensi derajat 1 sebanyak 143 orang $(37,6 \%)$ dan pada pasien hipertensi derajat 2 sebanyak 237 orang $(63,4 \%)$. Hasil ini sejalan dengan penelitian yang dilakukan oleh Evi Sinaga (2011) di RS Pematang Siantar sebanyak $66,2 \%$ menderita hipertensi derajat 2. ${ }^{6}$ Adapun terapi pada pasien hipertensi esensial terbagi menjadi dua. Yang pertama adalah terapi non farmakologi yang terdiri atas mengurangi serta menghentikan rokok, menurunkan berat badan berlebih, menurunkan konsumsi alkohol berlebih, melakukan latihan fisik secara rutin, menurunkan asupan garam, dan meningkatkan asupan sayur juga buah-buahan. Adapun target pengobatan untuk hipertensi esensial adalah mencapai target tekanan darah $<140 / 90 \mathrm{mmHg}$ dan untuk individu yang memiliki resiko tinggi terjadinya diabetes dan penyakit ginjal maka target penurunan tekanan darah adalah $<130 / 80 \mathrm{mmHg}^{2}$

Dari tabel 6. didapatkan sebanyak 277 pasien hipertensi esensial tidak disertai dengan penyakit penyerta atau sekitar $72,9 \%$. Adapun pada tabel 7 . didapatkan penyakit penyerta hipertensi adalah diabetes melitus $61,2 \%$, disusul penyakit jantung koroner $12,6 \%$, stroke $12,6 \%$, gagal jantung $6,8 \%$, pasien pasca infark miokard $3,9 \%$, dan penyakit gagal ginjal kronik dengan 2,9\% dari total 103 pasien hipertensi. Hasil penelitian ini sama dengan penilitian yang dilakukan oleh Evi Sinaga (2011) yang mendapatkan pada pasien hipertensi disertai diabetes melitus menempati posisi pertama dengan 33,3\% dari total pasien yang menjalani perawatan di Rumah Sakit Vita Insani Pematang Siantar tersebut.

Tabel 8. menyajikan obat yang digunakan pada terapi hipertensi. Dari tabel tersebut didapatkan HCT menempati posisi pertama $(35,5 \%)$, captopril (26,2\%), valsartan (20,6\%), amlodipin (15,2\%), furosemid $(1,4 \%)$, atenolol $(1,1 \%)$. Penggunaan obat golongan diuretik sebagai pilihan pertama obat antihipertensi pada orang tua karena tidak ada perbedaan signifikan dalam menurunkan tekanan darah maupun dalam menurunkan mortalitas serta dilihat dari segi biaya penggunaan diuretik lebih murah. Pengecualian pada pasien dengan indikasi khusus untuk penggunaan golongan lain seperti pasien dengan pasca infark miokard (penyekat beta dan ACE-inhibitor), pasien dengan diabetik nefropati (ACE-inhibitor, ARB). Sebagai terapi pertama biasanya digunakan sebagai tambahan. Jika dibutuhkan kombinasi 3 macam obat maka dapat diberikan diuretik, ACE-inhibitor atau ARB dan CCB. ${ }^{2}$

\section{KESIMPULAN}

Pasien hipertensi esensial tanpa disertai oleh penyakit penyerta sebanyak 277 pasien atau sebanyak $72,9 \%$. Adapun terapi yang paling sering diberikan pada pasien hipertensi tanpa penyakit penyerta menggunakan golongan diuretik karena dinilai paling aman dan efektif.

Pasien hipertensi yang disertai dengan penyakit penyerta sebanyak 103 pasien atau sebanyak $27,1 \%$ dari keseluruhan pasien. Penyakit penyerta terbanyak pada penderrita hipertensi esensial adalah diabetes melitus dengan jumlah 
sebanyak 63 pasien atau 61,2\% dari 103 pasien hipertensi yang disertai dengan penyakit penyerta. Kombinasi obat yang paling sering pada hipertensi esensial yang disertai dengan penyakit penyerta ini adalah dari golongan diuretik dan ACE-inhibitor atau dari golongan diuretik dan ARB.

\section{DAFTAR PUSTAKA}

1. Shapo L, Pomerleauv J, McKee M. Epidemiology of hypertension and associated cardiovaskular risk factor. Journal Epidemiology Community Health. 2003; 57 (9): 734-39.

2. Yogiantoro, M. Hipertensi esensial. Dalam: Buku
Ajar IImu Penyakit Dalam Jilid II. Edisi ke-5. Jakarta: Interna Publishing; 2009. HIm. 1079-85.

3. NIH. The Seven report of the joint national committee on prevention, detection, evaluation, and treatment of high blood pressure/JNC. NIH Publishing; 2003.

4. Mansjoer A. Kapita selekta kedokteran Jilid I. Jakarta: Media Aesculapius; 2001. HIm. 520.

5. Bustan M. Epidemiologi penyakit tak menular. Jakarta: Rineka Cipta; 2007. hlm 29-38.

6. Sinaga E. 2011. Karakteristik penderita hipertensi di rumah sakit Vita Insani Pematang Siantar. Medan: USU Press. 2011. 